\title{
National Health Insurance Scheme: A pathway to a sustained access to medicine in
}

\section{Nigeria}

Uguru Nkoli P., 2,3, Ogu Udochukwu U. ${ }^{3}$, Uguru Chibuzo C. ${ }^{4} \&$ Ibe Ogochukwu ${ }^{2}$

1: Department of Preventive Dentistry, Faculty of Dentistry, College of Medicine University of Nigeria Enugu Campus

2: Department of Health Administration and Management, Faculty of Health Sciences and Technology, University of Nigeria Enugu Campus

3: Health Policy Research Group, Department of Pharmaco-therapeutics, College of Medicine, University of Nigeria, Enugu Campus

4: Department of Oral and Maxillo-facial Surgery, Faculty of Dentistry, College of Medicine, University of Nigeria Enugu Campus.

\section{Corresponding author:}

Ogu Udochukwu Ugochukwu

udo2ogu@gmail.com

Word count: 3,645 
medRxiv preprint doi: https://doi.org/10.1101/2020.06.23.20138164; this version posted June 23, 2020. The copyright holder for this preprint

\section{Abstract}

2 Objective: The National Health Insurance Scheme (NHIS) has at its aim the need to ensure

3 that every Nigerian has equal access to good quality health care services. So far, only the

4 Formal Sector Social Health Insurance Program (FSSHIP) aspect of the scheme has been

5 fully activated. The question remains, why the delay towards universal coverage?

6 Design: The study was a cross-sectional and mixed method design. Both qualitative and 7 quantitative methods were utilized for the study.

8 Setting: This study was conducted in NHIS accredited facilities in Enugu State.

9 Participants: A sample of 300 enrolees were selected randomly. For the qualitative study, 6 10 in-depth interviews (IDIs) were conducted face to face with NHIS desk officers across the 11 three tiers of health care represented.

12 Results: The qualitative findings shows that $94.9 \%$ of respondents sought medical help. $1378.4 \%$ of the respondents indicated that the scheme improved their access to care. The 14 qualitative finding found that there was no discrepancy in access among socio-economic 15 groups. NHIS was reported to have improved access to medicine over the years. In the 16 qualitative, majority of the IDI respondents stated that many of the staff in NHIS 17 accredited facilities are not trained on what is expected or required of them with regards 18 to the scheme.

19 Conclusion: A focus on accessibility, affordability and availability for the scheme means that on account of either of the three, all facility categories and their interests must be considered in further planning of the scheme to ensure that things hold up fine.

22 Keywords: Access to medicine, National Health Insurance Scheme, Universal Health 23 Coverage, Nigeria.

\section{Article Summary}

- The study participants were only from one state.

- The study only focused on NHIS and NHIS accredited facilities. 


\section{Introduction}

32 Health is the entry point for breaking the vicious circle of ill health, poverty and under33 development and transforming it to improved health status, sustainable development and 34 prosperity (1). Countries across the world in this present time view health insurance as a means to ensure access to health care and protecting patients from financial risks $(2,3)$. Many African countries including Nigeria has established their version of health insurance (4).

The National Health Insurance Scheme (NHIS) which was established with decree 35 of 1999 has at its aim the need to ensure that every Nigerian has equal access to good quality health care services (2). The actual implementation of the NHIS commenced in 2002 and was consolidated in 2005 (2,5). Aspects of the scheme are; Formal Sector Social Health Insurance Program (FSSHIP), the Urban Health Self-employed Social Health Insurance Program (USSHIP) and Rural Community Social Health Insurance Program (RCSHIP), this is a community based health insurance model (5). So far, only the FSSHIP aspect of the scheme has been fully activated. The question remains, why the delay towards universal coverage?

45 Any health insurance program directed or aimed towards the benefit of the public should 46 consider the following, availability, accessibility and affordability (6). Availability in this 47 instance would mean the existence of adequate staff (skills-mix), drugs and equipment. 48 According to Goudge, Gilson, Russell, Gumede and Mills (7), the shortage of health service 49 often means that appropriate care is not available. Global health workforce alliance (GHWA)

50 (8) posits that availability is the adequate supply and appropriate stock of health workers who 51 have the competency and skill set to match the health needs of the population. Accessibility 52 according to GHWA (8) involves the equitable distribution of health workers by taking into 53 account the demographic composition of rural - urban mix and under-developed areas of the 54 population. Affordability, according to Axene (9) is the ability to purchase a good or service. 55 Affordability determines if a person or organization with limited resources is able to make a 56 purchase or has sufficient income to pay for health care costs (9).

57 A longitudinal study (7) done, in South Africa on affordability, availability and acceptability 58 barriers to health care for the chronically ill, showed that livelihood exhausted from previous 59 illness and death, low income and limited social network prevented initial healthcare 
60 consultations. On the other hand, the monthly expenditure from repeated consultation with

61 possibility of referral to other centers and use of ambulance services was observed to be

62 about $60 \%$ of income further hampering access (7). Thus in order to improve access to good

63 quality healthcare, more emphasis should be placed on access to the public sector. The focus

64 should be on improving drug supply chains, ambulance services, clinical capacity at public

65 clinics and most importantly addressing the financial constraint faced by the socially

66 disadvantaged. It is also imperative to think through how providers engage with patients in a

67 way that strengthens their therapeutic alliance.

68 Rekha, Wajid, Radhakrishnan and Matthew (10) measured accessibility index using a three

69 step floating catchment area in a geographical framework. Three variables were considered;

70 attractiveness of health care centre, travel time or distance between the location of the service

71 centre and residence and population demands for health care facilities.

72 Another study (11), found that respondents who described quality with regards to the ease 73 with which they got care or short waiting time as good, are 3.9 times more likely to have 74 private facilities as their chosen health care providing facility. Also the data collected 75 indicated that cost for service is 2.9 times more likely to predict the use of public health 76 facility as the usual health provider.

77 Inadequacies in quality of workforce affects improvement in health outcomes. Given that 78 without these three, availability, accessibility and affordability together, healthcare outcomes 79 in Nigeria will continually be poor. Despite the several failures of the Nigerian health care 80 system, some studies suggest that if managed well, the NHIS could be a useful ground for 81 good health care delivery (12). The purpose of this study therefore, is to emphasize the 82 importance of or role played by access (availability, accessibility and affordability) towards 83 the successful implementation of the NHIS (especially towards its universal coverage goals).

\section{Methods}

85 The study was a cross-sectional and mixed method design. Both qualitative and quantitative 86 methods were utilized for the study.

\section{$87 \quad$ Study setting}

88 This study was conducted in NHIS accredited facilities in Enugu State. The state is situated in 89 the south east part of the country with a population of 4,411,100 million with an annual 90 population growth of 3.0 (13). The state has three senatorial zones (Enugu north, east and 
medRxiv preprint doi: https://doi.org/10.1101/2020.06.23.20138164; this version posted June 23, 2020. The copyright holder for this preprint

91 west) with 17 local governments. In addition, there are 962 health facilities comprising 4 92 tertiary, 148 secondary (96 private and 52 public) and 774 (492 public and 282 private)

93 primary health facilities. The federal government funds and operates three tertiary health

94 facilities. One tertiary facility is operated by the state (14).

95 Data collection methods

96 A minimum sample size of 274 respondents was calculated using sample size calculation 97 for community survey. $10 \%$ was added to accommodate non-responders thus increasing 98 respondents surveyed to 300. Respondents were drawn from the beneficiaries of the 99 National Health Insurance scheme which are federal civil servants in Enugu State. A 100 sample of 300 enrolees were selected randomly. The questionnaires were interviewer 101 administered and they contained questions eliciting information on socio-demographic 102 details, availability of needed medicines, affordability of needed medicines, perception of 103 quality of medicines and patient satisfaction. For the qualitative study, 6 in depth 104 interviews (IDIs) were conducted face to face with NHIS desk officer across the three 105 tiers of health care represented. The IDIs focused on issues regarding access to 106 medicines. The IDI guide explored issues regarding existing governance and medicine 107 policy within the NHIS, Supply of medicines (market forces), health information 108 capacity, human resources, health financing and service delivery. All data collection tools 109 were pretested before use in the study.

110 Data Analysis

111 Analysis for quantitative data was done using STATA 11. Frequency and percentages 112 were computed as well as test of association between dependent and independent 113 variables. Chi-square tests were used to determine the test for associations and 114 differences. All tests of significance were carried out at a $p$ value $\leq 0.05$. Data was 115 presented in tables, and narratives as in the result section. For qualitative analysis, 116 interviews were transcribed verbatim. The main themes were identified from responses, 117 coded and analysed using NVivo 11.

118 Patient and Public Involvement

119 Those involved in the research gave verbal and signed consent.

120 Results

121 Demographic characteristics 
medRxiv preprint doi: https://doi.org/10.1101/2020.06.23.20138164; this version posted June 23, 2020. The copyright holder for this preprint

(which was not certified by peer review) is the author/funder, who has granted medRxiv a license to display the preprint in perpetuity.

All rights reserved. No reuse allowed without permission.

122296 out of 300 questionnaires were filled correctly. $67.6 \%$ were females and $32.4 \%$.

123 Primary beneficiaries comprised $68.2 \%$ of the respondents. $72.6 \%$ were under paid

124 employment, $9.8 \%$ were self-employed and $6.1 \%$ were self-employed (see Table 1).

125

126 Table 1: Demographic characteristics

\begin{tabular}{|l|l|}
\hline Variables & Frequency (\%) \\
\hline Gender & $96(32.4)$ \\
Female & $200(67.6)$ \\
Total & $296(100.0)$ \\
\hline Primary Beneficiary & \\
No & $94(31.8)$ \\
Yes & $202(68.2)$ \\
Total & $296(100.0)$ \\
\hline Employment status & $18(6.1)$ \\
Unemployed & $29(9.8)$ \\
Self employed & $215(72.6)$ \\
Paid employment & $34(11.5)$ \\
Not applicable & $296(100.0)$ \\
Total &
\end{tabular}

127

128 Accessibility of the scheme

129 In order to understand the level of access to medicines, respondents were asked questions

130 on the kind of illnesses they had, and the level of access they had to medicines. $89.5 \%$ of

131 respondents, said they had acute health issues. 94.9\% of respondents sought medical

132 help. $78.4 \%$ of the [questionnaire] respondents indicated that the scheme improved their

133 access to care (see Table 2).

134 Table 2: The kind of illness respondents sought care for and whether the scheme has 135 improved their level of access

\begin{tabular}{|l|l|}
\hline Variables & Freq. (\%) \\
\hline Kind of illness & \\
Acute illness & $265(89.5)$ \\
Chronic illness & $10.5(100.0)$ \\
\hline
\end{tabular}




\begin{tabular}{|l|l|}
\hline Total & $31(296)$ \\
\hline Improved access to medicine & \\
Yes & $232(78.4)$ \\
No & $55(18.6)$ \\
Don't know & $9(3.0)$ \\
Total & $296(100.0)$ \\
\hline
\end{tabular}

137 For the qualitative, one of the IDI respondents believed that all "enrolees had good access to medicines. A few responses of IDI respondents regarding level of access showed are as follows; "access is above average" [ETH]; very good. You know many people are yet to understand the scheme but for the little I have worked here the scheme is ok." [SL]. There was no discrepancy in access among socio-economic groups. NHIS was reported to have improved access to medicine over the years; "it has actually given room for people that cannot afford health care to have access to health care. It has actually tried to improve at least marginally it has increased it a little bit. Some people usually just take anything from the patent medicine vendors but now they have access medication without paying. It has actually improved access. "[SL].

Affordability of the scheme

The study found that $82.4 \%$ of respondents indicated that costs were partly covered (See Table 3). However, $72.9 \%$ out of the $82.4 \%$ were under paid employment. The remaining $9.5 \%$ were either self- employed or unemployed. Socio-economically, among the $82.4 \%$ that indicated that costs were partly covered, $31.1 \%$ were among the poorest and others, $25.4,21.1 \%$ and $21.7 \%$ for the least poor, poor and very poor respectively. $82.8 \%$ of respondents indicated that medicines for treatment of common medical conditions are affordable for those with low-income (see Table 3). 
medRxiv preprint doi: https://doi.org/10.1101/2020.06.23.20138164; this version posted June 23, 2020. The copyright holder for this preprint (which was not certified by peer review) is the author/funder, who has granted medRxiv a license to display the preprint in perpetuity.

Table 3: Was cost covered?

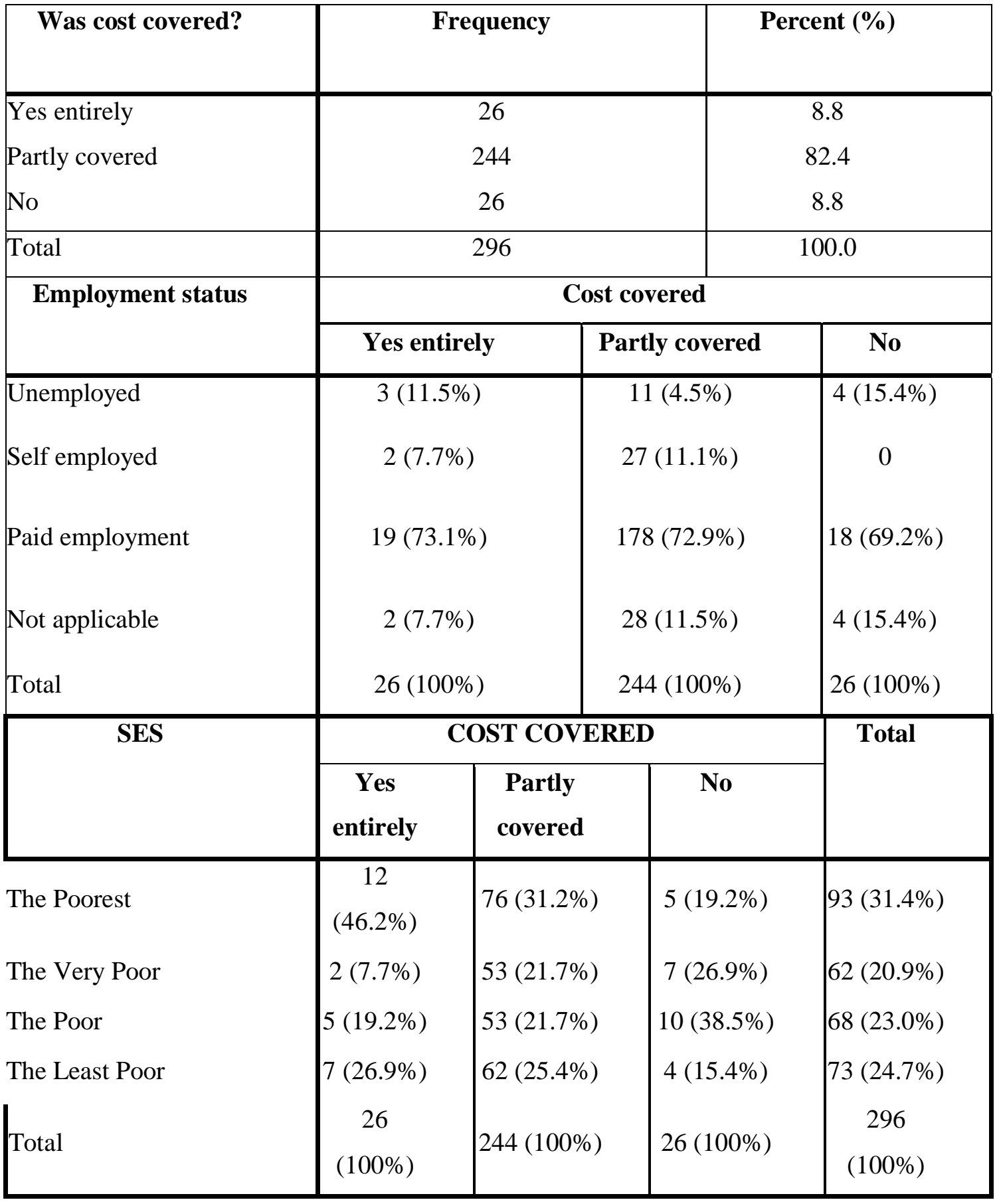




\begin{tabular}{|l|c|c|}
\hline $\begin{array}{c}\text { Affordability of drugs } \\
\text { for common medical } \\
\text { conditions for low - } \\
\text { income earners }\end{array}$ & Frequency & Percent \\
\hline Yes & & \\
No & 245 & 82.8 \\
Don't know & 21 & 7.1 \\
Total & 30 & 10.1 \\
\hline
\end{tabular}

According to data collected from IDI respondents, Majority of the respondents opined that NHIS which was designed to subsidize cost of services for users of healthcare is making the private institutions run at loss; the NHIS is structured in a way that the private institutions are at a loss as compared to the government institutions, because the government institutions have subvention from the government, the government takes care of their overhead while the private work out what they use. So they are already skewed." [SL]. The price list of drugs presently is not anything to write home about because the NHIS price is very much lower than what is obtainable in the market. These prices are detrimental to the finance of the institution, in other words if we continue, it is a way of running the hospital down and the policy cannot survive for a long time because a lot of private hospitals will opt out" [ETH].

\section{Availability of the scheme}

$78 \%$ of the respondents were of the opinion that the medicines on the scheme were of good quality (see Table 4). This is equally supported by findings from the IDI: "The medicines provided are good ones"[AMH]. "They give quality medicine. They give the best within the allocated funding” $[R C]$. Also, $83.8 \%$ indicated the drugs are effective (see Table 4). These drugs were not always available. When asked, $47.6 \%$ of the respondents were of the opinion that they were not always available, while $45.6 \%$ of them believed that the drugs were always available (see Table 4). An IDI respondent believes that "it depends on the health care provider. I can rate it between 50 and $60 \%$ depending on the provider but it's an individual access" [SL].

\section{Table 4: Drugs from the scheme}


medRxiv preprint doi: https://doi.org/10.1101/2020.06.23.20138164; this version posted June 23, 2020. The copyright holder for this preprint (which was not certified by peer review) is the author/funder, who has granted medRxiv a license to display the preprint in perpetuity.

\begin{tabular}{|l|c|c|}
\hline Quality of drugs & Frequency & Percent \\
\hline Yes & 231 & 78.0 \\
No & 33 & 11.1 \\
Don't know & 32 & 10.8 \\
Total & 296 & 100.0 \\
\hline Were drugs prescribed under the scheme & & \\
effective? & 248 & 83.8 \\
\hline Yes & 35 & 11.8 \\
No & 13 & 4.4 \\
Don't know & 296 & 100.0 \\
\hline Total & & \\
\hline Availability of drugs issued under the & 135 & 47.6 \\
scheme & 20 & 6.8 \\
\hline Yes & 296 & 100.0 \\
No & & \\
Don't know & & \\
Total & & \\
\hline
\end{tabular}

191 Staff availability for NHIS facilities were ranked low because in facilities surveyed, staff 192 were not readily available to attend to clients. Results showed that $65.5 \%$ indicated that they 193 had to wait long before receiving treatment (see Table 5). On the issue of difficulty in getting 194 medicine, 54.4\% never had difficulty getting medicine, while $42.6 \%$ encountered some 195 difficulties getting medicine (see Table 5). Respondents were asked if locally made drugs 196 were more available on the scheme than imported medicine, $49.3 \%$ didn't know, $42.6 \%$ 197 indicated "yes" and 8.1\% indicated "no" (see Table 5).

\section{Table 5: Staff availability}

\begin{tabular}{|l|c|c|}
\hline Do you wait long before receiving treatment? & Frequency & Percent \\
\hline Yes & 194 & 65.5 \\
No & 93 & 31.4 \\
Ton't know & 9 & 3.0 \\
\hline Did you have difficulty in getting medicine & 296 & 100.0 \\
\hline
\end{tabular}


medRxiv preprint doi: https://doi.org/10.1101/2020.06.23.20138164; this version posted June 23, 2020. The copyright holder for this preprint (which was not certified by peer review) is the author/funder, who has granted medRxiv a license to display the preprint in perpetuity.

All rights reserved. No reuse allowed without permission.

\begin{tabular}{|l|c|c|}
\hline Yes & 126 & 42.6 \\
No & 161 & 54.4 \\
Don't know & 9 & 3.0 \\
Total & 296 & 100.0 \\
\hline Are locally manufactured drugs more available & \multicolumn{2}{|l|}{} \\
on the scheme than imported drugs? & \multicolumn{2}{|l|}{} \\
\hline Yes & 126 & 42.6 \\
No & 24 & 8.1 \\
Don't know & 146 & 49.3 \\
Total & 296 & 100.0 \\
\hline
\end{tabular}

200 On staff availability, majority of the IDI respondents stated that many of the staff in NHIS

201 accredited facilities are not educated on what is expected or required of them with regards to 202 the scheme. They have very little knowledge on how to run the scheme. This is evidenced by 203 the statement below: “The desk officers are not even trained. The health care providers don't 204 even know what the scheme is all about... When you go to a hospital that is under NHIS, most 205 times the staff don't know what the scheme is all about".

\section{Discussion}

207 NHIS was established with the aim to reduce any negative effects of user fees and also to 208 help towards subsidizing the high health care expenses (15). This study sought to assess contextual nature of NHIS with emphasis/focus on accessibility, affordability and availability

210 (3As) and how focus on these three can make NHIS into a more beneficial and long-term scheme towards improving access to medicine.

212 The constraints to accessing medicines (from the supply side) focuses on healthcare service 213 provider/facilities (16). Among these constraints are facility/service location (17). The 214 scheme, has as one of its objectives, to ensure adequate distribution of health facilities within 215 the federation (18). This is far from realized. The implication of this to the accessibility of the 216 scheme, is that no matter the success recorded now by the scheme, it is still an indication of 217 how much more that needs to be done, especially in the area of accessibility. In order to 218 tackle this issue of accessibility, more facilities should be built proportionately and these 219 facilities across the globe, should be well equipped to handle at the very least, essential medical services. Equally, patients should be able to access the full benefits of the scheme 
medRxiv preprint doi: https://doi.org/10.1101/2020.06.23.20138164; this version posted June 23, 2020. The copyright holder for this preprint

221 from wherever they are within the country (irrespective of enrolment centre). Accessibility of

222 the scheme cannot be complete without the private hospitals buying in fully into the scheme.

223 The private hospitals are profit minded and to get them to truly buy in, their profit thirsts will

224 have to be quenched.

225 The NHIS has improved service utilization, this finding is in congruence with other studies $226(19,20)$. However, this improvement in utilization tilts a great deal towards salaried workers 227 of all cadre. Although it is of more benefit to low income workers. Low income workers who 228 would have otherwise not been able to have the funds to utilize essential medical services, 229 through the scheme, can now utilize said services. However, the percentage that fall under 230 this group (salaried workers) are nothing compared to a vast majority of unemployed citizens 231 living across the country, who are not able to utilize or have access to essential medical 232 services. More needs to be done in a bid to further improve access to medicine through the 233 scheme. NHIS was designed to cover part costs (10\%) for services. Due to the rising cost of 234 health care in the country, the NHIS sought primarily to create a means through which health 235 care can be affordable to all (20). Thus making user fees affordable for enrollees. The $10 \%$ co-payment paid by enrollees is the individual's commitment to the scheme. This creates opportunities for low income earners to afford health care. However, since the scheme only covers salaried workers, the unemployed (those without any means of livelihood) are still left to cater for the full cost of medical services unless they have a family member who enrolls them under their own package. Despite how long the scheme has existed, it's yet to go beyond the formal sector to cover those at the community level. Total access to essential medicine is still beyond reach.

243 Availability was another subject raised during the course of this study. Availability of drugs 244 and staff, are key factors in ensuring utilization and access to medicine (21). The drugs 245 provided by the scheme, though of good quality, were not always available. Often times, 246 patients/clients were sent out to the drug stores outside the facility to buy needed drugs. This 247 sometimes meant that they sometimes had difficulty getting medicine. Which could prove a 248 problem for patients in dire need of drugs. This challenge can be taken care by using local 249 pharmacies to dispense drugs free of charge, against the voucher issued to the patient by the 250 doctor. This local pharmacy, can then be reimbursed by the authorities (22). In addition to the 251 drugs, staff were known not to be readily available. This meant that enrollees had to wait long 252 before receiving treatment and this can often prove catastrophic for patients. Depending on 253 the emergency of their health problems, these enrollees may grow inpatient and may decide 
254 to use whatever funds they have left to seek medical care. For many of the facilities, even the 255 available staff has no clue as to what is expected of them. In other words, they lacked 256 adequate training needed in performance of their duties. Thus, in a manner of speaking, 257 affecting their relationship with clients and by extension, to access to essential medicine. 258 Therefore, if a patient suffers from a certain ailment, such patient should be able to obtain the 259 right treatment at first call. However, seeing as staff is not always available, this will most 260 likely not be the case (16).

261 NHIS has as its main objective achieving equitable access to health care in Nigeria (20). They 262 key to achieving this, is a focus on the 3As that matter most - accessibility, affordability and availability (16). The results of this study has already shown what focus on these three can achieve. So far, presence of the scheme alone has been reported to increase utilization and made it a bit more affordable. However, this is not enough as majority of the country's population are unemployed and are not part of anyone's benefit package. In line with this, studies $(23,24)$ have suggested that the organization and structure of the bio medical healthcare system of Nigeria, seems to lack in some of those basic components that could enhance access to healthcare. Obuaku (16) pointed out that there is inadequate access to health care services among a large percentage of the population and despite the reforms that has been made by the government, majority of the public health facilities are still shortstaffed, ill-equipped, and low on medicines, vaccines and treatments. It has been almost two decades since the introduction of the NHIS and the number of Nigerians covered by the scheme is less than $5 \%$ of the population and these are mostly civil servants and corporate workers (and their relatives) in the private sector (25) and those without insurance, who are in need of financial risk protection (more than 90\%), are expected to pay out of pocket (26).

Although the scheme has increased/improved utilization, by making the scheme a bit more affordable. There still remains a lot of challenges. These challenges with NHIS from the perspective of the $3 \mathrm{As}$ as found by this study, revolves mostly around access to drugs and availability of drugs. Especially regarding private hospitals. The low drug price, low service charge and the fact that they don't get to go by their own service charge but by that of the NHIS is considered a problem by some of the private hospitals. They believe that they are not making as much in profit as they should: instead of the hospital to be growing financially, it will be running down. If this continues, many hospitals might opt out. Also, there are cases where some of the enrollees develop resistance towards the drugs thus rendering the drugs ineffective. Equally, many of the drugs made available by the scheme have become 
adulterated. When these clients take it, they don't actually have the desired effect. Because of it, patients tend to lose confidence in some of these orthodox medicine. There is also, the mentality that anything from overseas is better than what we produced locally. Some prefer the drugs on the high amount than the lower amount because they feel it is more genuine. These information comes from the supply side.

Inadequate availability can be a deterrent to the accessibility of health care. If adequate facilities, skilled staff and (quality) drugs are available and accessible but not affordable, the health services might not be used. This shows the linkage between the 3As. According to World Bank (2019), a great number of Nigeria's population still live in poverty, without adequate access to basic services, and could benefit from more inclusive development policies. Thus, affordability, in a nation like Nigeria, may be the link that holds all three together and may well be a "golden parachute" towards universal coverage. If people find health services affordable, the number of those seeking healthcare will increase, thus creating a stronger need for health services to be made available and accessible. In all, improved access. However, poor funding of healthcare in Nigeria has been a major barrier to the quality of healthcare service delivery in recent times (26). Thus, the high burden of the costs for healthcare is being borne by individuals and households, which made Nigeria rank as the country with the second highest level of out-of-pocket spending on health in the world (26). There could be a connection between the implementation of NHIS and corruption because the money meant to boost the health sector, most often, ends up in private pockets, which then results to inadequate funding to execute the programme effectively (27). Therefore, availability, accessibility and affordability are structures that can only thrive if adequate funding is released to that effect.

\section{Study limitations}

The study only focused on the health insurance scheme provided by the government. It however, did not look at other health insurance schemes that are already in play or could be in play.

\section{Conclusion}

NHIS has been reported $(20,28)$ to contribute to an increase in health care utilization. However, the scheme is without its perks. A focus on the 3As (accessibility, affordability and availability) for the scheme means that on account of either of the three, all facility categories (private and public) and their interests (where necessary) must be considered in further 
planning of the scheme to ensure that things hold up fine. In other to ensure a universal coverage, all health care providers (be it private or public) be addressed from their own standpoints - private as private and public as public. Not as one.

Finally, the 3As become a focus when the governing body of the scheme take complete charge of NHIS units in hospitals (private or public) as separate departments or liaison unit, having government employed staff (doctors, nurses, labs, equipment, attendants etc) in all these units across all facilities (private or public). For the private facilities, these staff will be answerable to and paid by the government and not the facilities they operate from. Also, quality drugs and equipment put in use in these units, in all accredited facilities across the globe. Lastly, these staff will be properly trained for the tasks they are employed to carry out.

\section{Acknowledgement: Not applicable}

Ethics approval: This study was reviewed and approved by the Health Research Ethics Committee of the University of Nigeria Teaching Hospital, Ituku-ozalla, Enugu state, Nigeria with ID number NHREC/05/01/2008B-FWA00002458-1RB00002323

Funding statement: This research received no specific grant from any funding agency in the public, commercial or not-for-profit sectors.

\section{Competing interests: None declared.}

Data sharing: Technical appendix, statistical code, and dataset available from the lead author and the corresponding author.

Informed consent: Written informed consent was obtained from all participants through signatures, thumb prints or verbally. An information sheet, detailing the purpose of the study, proposed participants, and the rights of participants, was given to the participants and reiterated verbally by the researchers.

\section{Author contributions:}

Conceptualization: [Uguru Nkolika Pamela, Ibe Ogochukwu],

Methodology: [Uguru Nkolika Pamela, Ibe, Ogochukwu],

Formal analysis and investigation: [Uguru Nkolika Pamela, Ogu Udochukwu Ugochukwu], Writing-original draft preparation: [Uguru Nkolika Pamela, Ogu Udochukwu Ugochukwu, Uguru Chibuzo], 
medRxiv preprint doi: https://doi.org/10.1101/2020.06.23.20138164; this version posted June 23, 2020. The copyright holder for this preprint

(which was not certified by peer review) is the author/funder, who has granted medRxiv a license to display the preprint in perpetuity.

All rights reserved. No reuse allowed without permission.

348 Writing - review and editing: [Uguru Nkolika Pamela, Ogu Udochukwu Ugochukwu, Uguru

349 Chibuzo, Ibe Ogochukwu],

350 Resources: [Uguru Nkolika Pamela, Ogu Udochukwu].

351

352

353

354

References

355 1. Saka MJ, Isiaka SB, Akande TM, Saka AO, Agbana BE, Bako IA. Health related

356 policy reform in Nigeria: Empirical analysis of health policies developed and

357 implemented between 2001 to 2010 for improved sustainable health and development.

$358 \quad$ J Public Adm Policy Res. 2012;4(3):50.

359 2. Akinwale AA, Shonuga A, Olusanya O. Artisan reactions to national health insurance

$360 \quad$ scheme in Lagos state, Nigeria. 2014;

361 3. Yang W. China's new cooperative medical scheme and equity in access to health care:

362 evidence from a longitudinal household survey. Int J Equity Health. 2013;12(1):20.

366

367

368

4. Mohammed S, Sambo MN, Dong H. Understanding client satisfaction with a health insurance scheme in Nigeria: factors and enrollees experiences. Heal Res policy Syst. 2011;9(1):20.

5. Ewelukwa O, Onoka C, Onwujekwe O. Viewing health expenditures, payment and coping mechanisms with an equity lens in Nigeria. BMC Health Serv Res. 2013;13(1):87.

6. McIntyre DI, Thiede M, Birch S. Access as a policy-relevant concept in low-and middle-income countries. Heal Econ Policy Law. 2009;4(2):179-93.

7. Goudge J, Gilson L, Russell S, Gumede T, Mills A. Affordability, availability and acceptability barriers to health care for the chronically ill: longitudinal case studies from South Africa. BMC Health Serv Res. 2009;9(1):75.

8. Global Health Workforce Alliance (GBHWA). WHO | What do we mean by availability, accessibility, acceptability and quality (AAAQ) of the health workforce? [Internet]. 2014 [cited 2020 May 22]. Available from: 
medRxiv preprint doi: https://doi.org/10.1101/2020.06.23.20138164; this version posted June 23, 2020. The copyright holder for this preprint

https://www.who.int/workforcealliance/media/qa/04/en/

9. Axene D V. Health care affordability: a valuable concept in understanding our healthcare system challenges. Soc Actuar Heal Sect News. 2003;45:20-2.

10. Rekha RS, Wajid S, Radhakrishnan N, Mathew S. Accessibility analysis of health care facility using geospatial techniques. Transp Res Procedia. 2017;27:1163-70.

11. Uchendu OC, Ilesanmi OS, Olumide AE. Factors influencing the choice of health care providing facility among workers in a local government secretariat in south western Nigeria. Ann Ibadan Postgrad Med. 2013;11(2):87-95.

12. Okaro AO, Ohagwu CC, Njoku J. Awareness and perception of national health insurance scheme (NHIS) among radiographers in south east Nigeria. Am J Sci Res. 2010;8:18-25.

13. National Population Council. National Population Estimates [Internet]. 2016. Available from: https://www.google.com/url?sa=t\&rct=j\&q=\&esrc=s\&source=web\&cd=3\&ved=2ahU KEwj_7rbz5_ToAhUiD2MBHeliAkIQFjACegQIBBAC\&url=https\%3A\%2F\%2Fnige rianstat.gov.ng\%2Fdownload\%2F474\&usg=AOvVaw0B YliCMVsVxpAo4Ie9xgup

14. Enugu State Ministry of Health. List of Local Government Areas and Political Wards in Enugu State. Department Research Planning and Statistics. 2018.

15. Ilesanmi OS, Adebiyi AO, Fatiregun AA. National health insurance scheme: how protected are households in Oyo State, Nigeria from catastrophic health expenditure? Int J Heal policy Manag. 2014;2(4):175.

16. Obuaku C. Essential medicines in Nigeria: foregrounding access to affordable essential medicines. African Sociol Rev Africaine Sociol. 2014;18(2):42-60.

17. Cameron A, Ewen M, Ross-Degnan D, Ball D, Laing R. Medicine prices, availability, and affordability in 36 developing and middle-income countries: a secondary analysis. Lancet. 2009;373(9659):240-9.

18. Welcome MO. The Nigerian health care system: Need for integrating adequate medical intelligence and surveillance systems. J Pharm Bioallied Sci [Internet]. 2011 Oct;3(4):470-8. Available from: https://pubmed.ncbi.nlm.nih.gov/22219580 
medRxiv preprint doi: https://doi.org/10.1101/2020.06.23.20138164; this version posted June 23, 2020. The copyright holder for this preprint

19. Price DW, Swaney III RE, Xu S, Goodspeed JR, Steiner JF. Care of common medical conditions in a managed care program for uninsured adults. Perm J. 2003;7(1):27.

20. Akande TM, Salaudeen A, Babatunde O. The effects of national health insurance scheme on utilization of health services at Unilorin Teaching Hospital staff clinic, Ilorin, Nigeria. 2014;

21. Pariyo GW, Ekirapa-Kiracho E, Okui O, Rahman MH, Peterson S, Bishai DM, et al. Changes in utilization of health services among poor and rural residents in Uganda: are reforms benefitting the poor? Int J Equity Health. 2009;8(1):39.

22. Sharma S, Chaudhury RR. Improving availability and accessibility of medicines: a tool for increasing healthcare coverage. Arch Med. 2015;5:12.

23. Fawibe AE, Onyedum CC, Sogaolu OM, Ajayi AO, Fasae AJ. Drug prescription pattern for asthma among nigerian doctors in general practice: A cross-sectional survey. Ann Thorac Med. 2012;7(2):78.

24. Alakija W. Essentials of community health, primary health care and health management. 2000;

25. Uzobo E, Ayinmoro AD. Health effects of the National Health Insurance Scheme (NHIS): A study among federal civil servants in Bayelsa State, Nigeria. J Heal Soc Sci. 2019;4(2):265-76.

26. Obikeze E, Onwujekwe O, Uzochukwu B, Chukwuogo O, Uchegbu E, Soludo E, et al. Benefit incidence of national health insurance scheme in enugu state, Southeast Nigeria. African J Heal Econ. 2013;2:13-30.

27. Oba JO. Nigeria: Yar'Adua and the resuscitation of health sector. http//allatrica com/stories/200806021431 html Retrieved Oct. 2008;22:2013.

28. Sanusi RA, Awe AT. Perception of national health insurance scheme (NHIS) by health care consumers in oyo state, Nigeria. Pakistan J Soc Sci. 2009;6(1):48-53. 